\title{
SOIL BACTERIAL DIVERSITY AND COMPOSITION OF DIFFERENT FOREST TYPES IN GREATER XING'AN MOUNTAINS, CHINA
}

\author{
SONG, D. D. - REN, L. - LI, X. - MA, D. L. ${ }^{*}$-ZANG, S. Y. \\ College of Geographical Sciences, Harbin Normal University, Harbin 150025, PR China \\ *Corresponding author \\ e-mail: madalong728@163.com
}

(Received $1^{\text {st }}$ Jan 2021; accepted $18^{\text {th }}$ Mar 2021)

\begin{abstract}
Soil microorganisms are an important component of forest ecosystems and have an important role in maintaining ecosystem stability. High-throughput sequencing technology was used to analyze the microbial composition and diversity of three typical forest, including Larix gmelinii forest (LG), Pinus sylvestris forest (PS), and Betula platyphylla forest (BP) in the Greater Xing'an Mountains, China. The results showed that there were significant differences in soil physical and chemical properties ( $\mathrm{pH}$, total organic carbon, total nitrogen and total phosphorus) among the three forest types. Soil bacterial alpha diversity (Shannon and Simpson) was not significantly different between forest types, but principal co-ordinates analysis $(\mathrm{PCoA})$ results showed that soil bacterial beta diversity varied significantly (PERMANOVA: $R^{2}=0.5014, P<0.01$ ). In the three forest types of soil, the composition of the dominant bacterial phyla was basically the same. The relative abundance of Acidobacteria in BP soil was $34.64 \%$, Proteobacteria was $27.00 \%$, Chloroflexi was $10.32 \%$; the relative abundance of Proteobacteria in LG soil dominant bacteria was $30.62 \%$, Acidobacteria was $18.31 \%$, Actinobacteria was $16.01 \%$; the relative abundance of Proteobacteria in PS soil was $25.54 \%$, Acidobacteria was $24.59 \%$, Actinobacteria was $16.46 \%$. Redundancy analysis (RDA) results showed that $\mathrm{pH}, \mathrm{TP}, \mathrm{TN}$ and TOC were the main environmental factors affecting the soil bacterial community structure. The findings of this study are intended to provide a new perspective on microbial ecology for a deeper understanding of the biogeochemical cycle in forest soils in the Greater Xing'an Mountains, China.
\end{abstract}

Keywords: forest types, permafrost, high-throughput sequencing, soil bacterial community, diversity, soil properties

\section{Introduction}

Microorganisms are the most active part of the forest ecosystem and the key driving force for the formation and transformation of soil materials (Curlevski et al., 2010). Throughout the formation and development of soil, it plays an irreplaceable role in the soil carbon and nitrogen cycle (Demeter et al., 2018), nutrient conversion (Wakelin et al., 2016), plant productivity (Friggens et al., 2019), maintaining soil structure (Banerjee et al., 2018). It is one of the indispensable indicators for evaluating soil quality (Ryan et al., 2012 and $\mathrm{Tu}$ et al., 2015). Soil microbial diversity refers to the types of all microorganisms contained in the soil ecosystem, the genes they possess, and the degree of diversity in the interaction between these microorganisms and the surrounding environment (Tardy et al., 2015). Forest ecosystems play an important role in regulating the global material balance. Exploring the differentiation patterns of soil microbial communities under different forest vegetations is an important part of understanding forest ecosystem functions.

Greater Xing'an Mountains is located in the high latitude permafrost region in the northern hemisphere. It is one of the regions most affected by climate change and 
human activities in our country and in the world. Greater Xing'an Mountains is also the only cold temperate coniferous forest area in China, which has an irreplaceable role and position in maintaining the ecological balance of northeastern, China (Luo et al., 2018). In recent years, due to the effects of human interference and the degradation of permafrost in this area, forest productivity has decreased, vegetation reverse succession has accelerated, and the tree line of plantation trees has risen ( $\mathrm{Li}$ et al., 2018). Nowadays, this local forest vegetation composition has been transferred from original conifer type (Larix gmelinii) into broad-leaved types (Betula platyphylla, Populus davidiana and Quercus mongolica). These changes will have a huge impact on the regional ecosystem and break the existing soil microbial composition structure. Moreover, changes in soil microbial community and function also impact aboveground plant composition and diversity (Siles and Margesin, 2016). Therefore, soil microorganisms are of great significance to the forest ecosystem and have critical roles in vegetation renewal and successional processes. This study of how vegetation impacts soil microbes is an increasingly popular topic for ecologists, especially research regarding the functional mechanisms of ecosystems. Therefore, clarifying the characteristics and evolution rules of forest soil microbial communities in the Greater Xing'an Mountains is the key grasping the biogeochemical cycle process in the cold region, and the correspondence is of great significance to global change.

The different types of litter and root exudates undertaken by soil under different forest vegetations will inevitably have a significant impact on microbial diversity and community structure (Ren et al., 2017). In order to further clarify the coupling relationship and the mechanism between vegetation and microbes, this paper using different forest types of soil in Greater Xing'an Mountains microorganisms are the research objects. We hypothesis: 1) how the soil bacterial community structure and diversity varied from long-term forest succession process? 2) Soil physico-chemistry properties were key factors affecting the bacterial community composition. Illumina Miseq high-throughput sequencing technology was used to sequence and analyze the $16 \mathrm{~S}$ rRNA genes of bacteria in soil samples. It aims to provide a perspective of microbial ecology for a deeper understanding of the microbial structure and function of the forest soils in the Greater Xing'an Mountains.

\section{Materials and methods}

\section{Study area}

The research area is located in Mohe Forest Ecosystem Research Station in Mohe County, Heilongjiang Province, China. The climate belongs to the continental monsoon climate in the cold temperate zone. The summer is mild and short, and the winter is long and cold. The annual average temperature is $-4.9{ }^{\circ} \mathrm{C}$, the extreme minimum temperature is $-49.5^{\circ} \mathrm{C}$, the frost-free period is $85-105 \mathrm{~d}$, and the annual precipitation is $350-500 \mathrm{~mm}$, mostly concentrated in summer, which accounted for $60-70 \%$ of annual total precipitation. The typical zonal vegetation is dominated by Larix gmelinii, Pinus sylvestris var. mongolica, Betula platyphlla, and Populus davidiana. The soil is dark brown forest soil (Dong et al., 2019). Due to human interference such as logging or fire, a large number of Larix gmelinii forests have been destroyed and large areas of secondary Betula platyphylla forests have been derived. 


\section{Soil sample collection}

Three typical $100 \mathrm{~m} \times 100 \mathrm{~m}$ fixed experimental plots were selected in typical locations with similar site conditions (Table 1), including the main forest types Larix gmelinii forest (LG), Pinus sylvestris forest (PS), and Betula platyphylla forest (BP), and 3 quadrats of $20 \mathrm{~m} \times 20 \mathrm{~m}$ each in different forest plots (Fig. 1). At the beginning of May 2019, the active soil layer was in a rapid melting stage, and the temperature gradually increased. The upper soil layer was in a melting state (average depth of about $23 \mathrm{~cm}$ ), while the lower part was still frozen, respectively. Collect 5 samples of the melting active layer $(0-20 \mathrm{~cm})$ in the sample area according to the " $\mathrm{S}$ " route. After removing debris, tree roots and other debris, seal them in a sterilized ziplock bag and bring them back to the laboratory. The soil sample was evenly mixed and divided into 2 parts. One part was air-dried through a $2 \mathrm{~mm}$ sieve for the determination of soil physical and chemical properties. The other part was stored in a refrigerator at $-80{ }^{\circ} \mathrm{C}$ and used for determination of soil microorganism sequence within one week.

Table 1. Basic overview of three forest type plots

\begin{tabular}{c|c|c|c|c|c|c|c}
\hline Forest types & $\begin{array}{c}\text { Latitude } \\
(\text { North) }\end{array}$ & $\begin{array}{c}\text { Longitude } \\
(\text { East })\end{array}$ & $\begin{array}{c}\text { Altitude } \\
(\mathbf{m})\end{array}$ & Slope $\left({ }^{\circ}\right)$ & Aspect & $\begin{array}{c}\text { Canopy } \\
\text { density }\end{array}$ & $\begin{array}{c}\text { Active soil } \\
\text { layer }(\mathbf{m})\end{array}$ \\
\hline Larix gmelinii forest & $53^{\circ} 28^{\prime} 03.2^{\prime \prime}$ & $122^{\circ} 20^{\prime} 38.6^{\prime \prime}$ & 320 & 9 & Northeast & 0.8 & $0.8-1.5$ \\
Pinus sylvestris forest & $53^{\circ} 28^{\prime} 03.3^{\prime \prime}$ & $122^{\circ} 21^{\prime} 07.6^{\prime \prime}$ & 305 & 10 & Northeast & 0.7 & $1.1-1.8$ \\
Betula platyphylla forest & $53^{\circ} 26^{\prime} 32.4^{\prime \prime}$ & $122^{\circ} 12^{\prime} 18.0^{\prime \prime}$ & 336 & 12 & Northeast & 0.8 & $1.5-2.5$ \\
\hline
\end{tabular}

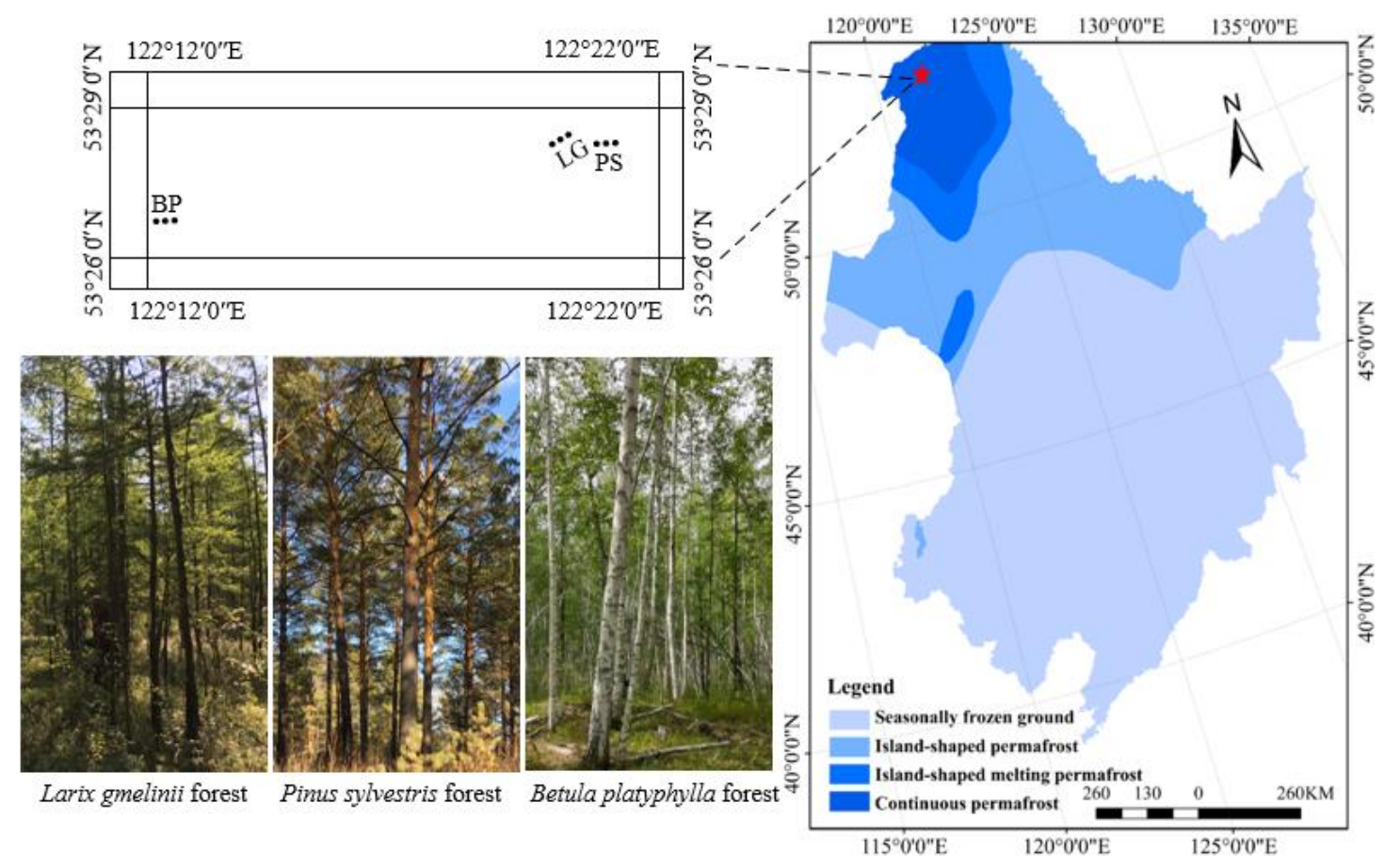

Figure 1. Map of the study site

\section{Determination of physical and chemical properties of soil samples}

Determination of soil moisture content: put the fresh soil sample back into the aluminum box and weigh it on the balance, accurate to $0.01 \mathrm{~g}$, tilt the box lid on the 
aluminum basin, and put it into the preheated to $10 \pm 2{ }^{\circ} \mathrm{C}$. Bake in a constant temperature drying oven for $8 \mathrm{~h}$, and take out the weighing calculation; the soil $\mathrm{pH}$ is measured with an acid meter (PHSJ-3F, INESA Scientific Instrument Co., Ltd, China) with a water-soil ratio of 2.5:1; the TOC and TN were measured by an elemental analyzer (VarioEL III, Elementar Analysensysteme GmbH, Germany). Total phosphorus: The $\mathrm{NaHCO}_{3}$ extraction and $\mathrm{HClO}_{4}-\mathrm{H}_{2} \mathrm{SO}_{4}$ digestion approaches were implemented to identify the total phosphorus.

\section{DNA extraction and high-throughput sequencing}

Using the Power Soil DNA extraction kit (MoBio Laboratories, USA), according to the instructions, weigh $0.5 \mathrm{~g}$ of fresh soil and extract genomic DNA from all soil samples $(n=9)$. The extracted genomic DNA was detected by $1 \%$ agarose gel electrophoresis. Universal primers 338F (5'-ACTCCTACGGGAGGCAG CA-3') and 806R (5'-GGACTACHVGGGTWTCTAAT-3') were used for bacterial 16S rRNA genes. The amplified product was detected by $2 \%$ agarose gel electrophoresis, and recovered from the gel using the AxyPrep DNA gel extraction kit (Axygen Biosciences, USA), washed with Tris- $\mathrm{HCl}$, and verified by $2 \%$ agarose gel electrophoresis. Use the QuantiFluor ${ }^{\mathrm{TM}}$-ST fluorometer to quantify the polymerase chain reaction (PCR) products, and adjust the samples as necessary for sequencing. Sequencing was performed by Shanghai Majorbio Bioengineer Co., Ltd. (Shanghai, China) using the Illumina MiSeq platform.

\section{S rRNA gene sequence analysis}

The original fastq sequence file is quality filtered by Trimmomatic, and then stitched by FLASH, which requires to meet the following standards: (i) 2 nucleotide mismatches are allowed, and delete the fragments containing ambiguous bases; (ii) sequences with an overlap length exceeding $10 \mathrm{bp}$ are merged according to their overlapping sequences; (iii) a sequence less than $50 \mathrm{bp}$ and an average quality score of less than 20. Using UPARSE, the operational taxonomic unit (OTU) is classified with $97 \%$ similarity, and UCHIME is used to identify and remove chimeric sequences. The classification of all 16S rRNA gene sequences was analyzed by the ribosomal database project (RDP) classification algorithm against the Silva (SSU123) 16S rRNA database.

\section{Statistics analysis}

Use Mothur software to calculate community diversity parameters (Simpson, Shannon-Wiener index) and community richness parameters (Chao, ACE index) that belong to alpha diversity analysis. Principal co-ordinates analysis (PCoA) was performed by using the $\mathrm{R}$ software to visually analyze based on vegan package, and calculate the redundancy analysis (RDA) based on the OTU level. One-way analysis of variance (ANOVA) was used to analyze the effects of different forest types on soil physico-chemistrical properties and microbial diversity, and Duncan test was used to test the significance of each indicator between different forest types $(\alpha=0.05)$. All sample results are mean \pm standard deviation (SD). The result of $P<0.05$ between groups was proved to be statistically significant. 


\section{Results}

\section{Changes in soil physical and chemical properties under different forest types}

The soil physical and chemical properties of different forest types in Greater Xing'an Mountains were obviously different (Table 2). The soil $\mathrm{pH}$ range was 4.49 5.67, indicating that the soils of the three forest types were acidic, and the lowest $\mathrm{pH}$ value of the BP was 4.49, which was significantly lower than that of the other two forest types $(P<0.05)$. The soil water content (SWC) in three different forest types differed significantly, the SWC of PS (36.36\%) was highest and SWC of LG $(27.95 \%)$ was lowest. Total organic carbon (TOC) in three different forest types differed significantly, which the TOC of PS $(57.86 \mathrm{~g} / \mathrm{kg})$ was highest and the TOC of BP $(34.93 \mathrm{~g} / \mathrm{kg})$ was lowest. Total nitrogen $(\mathrm{TN})$ in three different forest types differed significantly, which the TN of LG $(5.37 \mathrm{~g} / \mathrm{kg})$ was highest and the TN of BP $(2.26$ $\mathrm{g} / \mathrm{kg}$ ) was lowest. Total phosphorus (TP) in three different forest types differed significantly, which the TP of LG was highest $(0.59 \mathrm{~g} / \mathrm{kg})$ and the TP of PS was lowest $(0.45 \mathrm{~g} / \mathrm{kg})$.

Table 2. Soil physical and chemical properties in different forest types

\begin{tabular}{c|c|c|c}
\hline $\begin{array}{c}\text { Soil physical and chemical } \\
\text { properties }\end{array}$ & $\begin{array}{c}\text { Larix gmelinii forest } \\
\text { (LG) }\end{array}$ & $\begin{array}{c}\text { Pinus sylvestris forest } \\
\text { (PS) }\end{array}$ & $\begin{array}{c}\text { Betula platyphylla } \\
\text { forest (BP) }\end{array}$ \\
\hline $\mathrm{pH}$ & $5.67 \pm 0.31 \mathrm{a}$ & $5.48 \pm 0.24 \mathrm{a}$ & $4.49 \pm 0.16 \mathrm{~b}$ \\
Soil Water Content $(\%)$ & $27.95 \pm 2.48 \mathrm{c}$ & $36.36 \pm 2.05 \mathrm{a}$ & $32.71 \pm 1.53 \mathrm{~b}$ \\
Total Organic Carbon $(\mathrm{g} / \mathrm{kg})$ & $49.27 \pm 3.73 \mathrm{~b}$ & $57.86 \pm 2.42 \mathrm{a}$ & $34.93 \pm 1.17 \mathrm{c}$ \\
Total Nitrogen $(\mathrm{g} / \mathrm{kg})$ & $5.37 \pm 0.23 \mathrm{a}$ & $4.45 \pm 0.34 \mathrm{~b}$ & $2.26 \pm 0.19 \mathrm{c}$ \\
Total Phosphorus $(\mathrm{g} / \mathrm{kg})$ & $0.59 \pm 0.05 \mathrm{a}$ & $0.45 \pm 0.02 \mathrm{c}$ & $0.51 \pm 0.09 \mathrm{~b}$ \\
\hline
\end{tabular}

The values in the table are mean \pm standard deviation; different letters indicate significant differences at the 0.05 level

\section{Soil bacterial OTU of different forest types}

The Venn result showed in Figure 2. There were 5080 soil bacterial OTUs in three forest types. Among them, there were 876 (34.91\%) soil bacterial OTU sequences shared in Larix gmelinii forest (LG), Pinus sylvestris forest (PS) and Betula platyphylla forest (BP). The lowest number of BP soil bacteria-specific OTUs was 114, accounting for $4.54 \%$ of the total, the highest LG soil bacteria-specific OTUs was 498, accounting for $19.85 \%$ of the total, and the PS soil bacteria-specific OTUs was 202, accounting for $8.05 \%$ of the total. The results of the data show that the number of bacterial OTUs was higher in the LG and PS soils, and the number of unique OTUs in the LG soil was the largest.

\section{Changes of soil microbial alpha and beta diversity in different forest types}

From Table 3, we can infer that the Shannon and Simpson indices did not differ significantly $(P>0.05)$, but the ACE and Chao1 indices differed significantly $(P<0.05)$. The Shannon index ranged from 5.51 (BP) to 5.70 (PS), and the Simpson index ranged from 0.009 (PS) to 0.013 (LG). The ACE index ranged from 1128.84 (BP) to 1576.15 (PS), and the Chao1 index ranged from 1128.84 (BP) to 1573.92 (PS), PS was significantly higher than BP and LG $(P<0.05)$. 


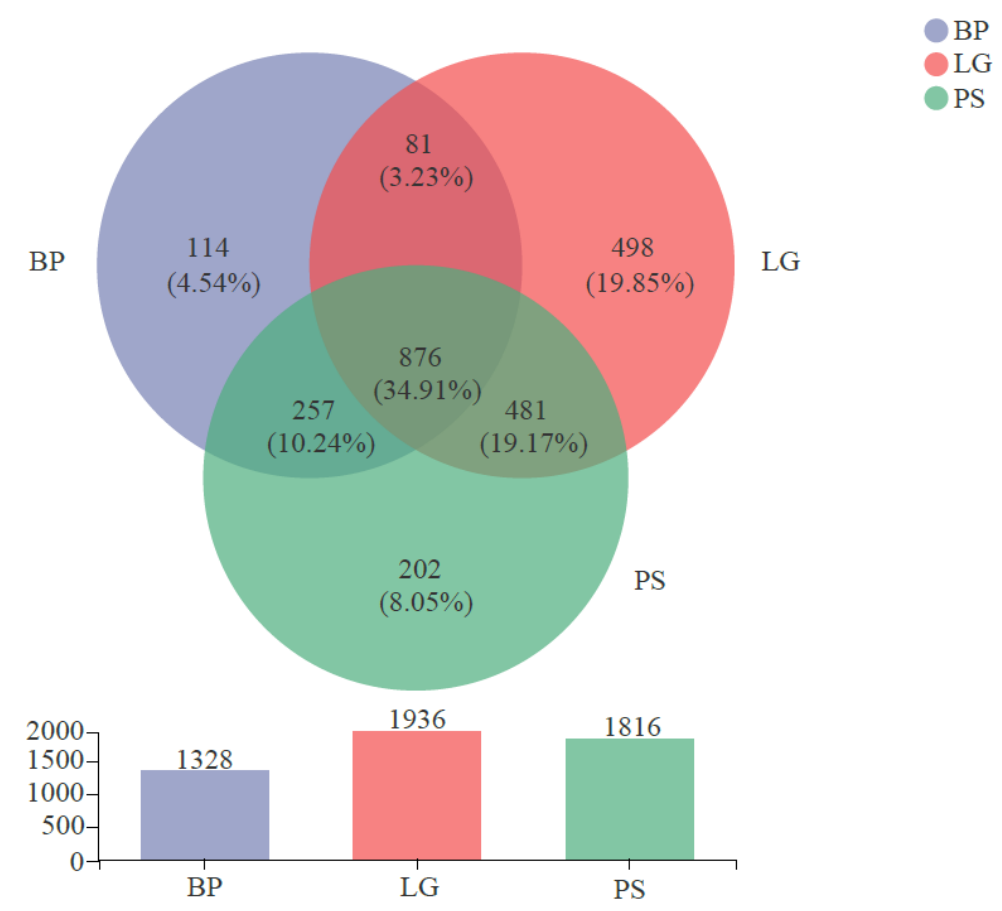

Figure 2. Venn diagram of bacterial community structure based on operational taxonomic unit (OTU) level of different forest types

Table 3. Soil bacterial alpha diversity in different forest types

\begin{tabular}{c|c|c|c|c}
\hline Forest type & Shannon & Simpson & ACE & Chao1 \\
\hline BP & $5.51 \pm 0.23 \mathrm{a}$ & $0.010 \pm 0.002 \mathrm{a}$ & $1128.84 \pm 41.84 \mathrm{~b}$ & $1128.84 \pm 60.69 \mathrm{~b}$ \\
LG & $5.58 \pm 0.46 \mathrm{a}$ & $0.013 \pm 0.009 \mathrm{a}$ & $1279.97 \pm 69.53 \mathrm{~b}$ & $1284.38 \pm 89.31 \mathrm{~b}$ \\
PS & $5.70 \pm 0.33 \mathrm{a}$ & $0.009 \pm 0.004 \mathrm{a}$ & $1576.15 \pm 63.08 \mathrm{a}$ & $1573.92 \pm 54.77 \mathrm{a}$ \\
\hline
\end{tabular}

Larix gmelinii forest (LG), Pinus sylvestris forest (PS), and Betula platyphylla forest (BP). The values in the table are mean \pm standard deviation; different letters indicate significant differences at the 0.05 level

The beta diversity of bacterial communities in different forest types was measured by PCoA of Bray-Crutis distance. The variance contribution rate of principal component 1 (PC1) was $41.89 \%$, and the contribution rate of principal component 2 (PC2) was $23.96 \%$, a total of $65.85 \%$ for the whole soil bacterial community composition (Fig. 3). The differences in bacterial community structure between different forest types are significant (PERMANOVA: $R^{2}=0.5014, P<0.01$ ), the differences within the samples are not significant, and the differences are mainly from different samples. Moreover, the bacterial community structures of PS and BP were similar but different with LG.

\section{Analysis of soil bacterial community structure composition in different forest types}

From the perspective of the overall bacterial community structure, all OTUs belong to 58 bacterial phyla. If the sequence cannot be classified to a known phylum level, the phyla were uniformly classified as "others". From the relative abundance on all phylum level of the three forest types, the predominant phyla in all samples were Proteobacteria (23.44\%), Acidobacteria (22.35\%), Chloroflexi (20.84\%), and Actinobacteria (14.13\%) (Fig. 4a). 
The soil bacterial composition of Betula platyphylla forest on phylum level showed in Figure $4 b$. The relative abundance of Acidobacteria in BP soil dominant bacteria was $34.64 \%$, Proteobacteria was $27.00 \%$, Chloroflexi was $10.32 \%$, Actinobacteria was $10.10 \%$. The soil bacterial composition of Larix gmelinii forest on phylum level showed in Figure $4 c$. The relative abundance of Proteobacteria in LG soil was $30.62 \%$, Acidobacteria was $18.31 \%$, Actinobacteria was $16.01 \%$, Chloroflexi was $14.58 \%$. The soil bacterial composition of Pinus sylvestris forest on phylum level showed in Figure $4 d$. The relative abundance of Proteobacteria in PS soil was $25.54 \%$, Acidobacteria was $24.59 \%$, Actinobacteria was $16.46 \%$, Chloroflexi was $13.67 \%$.

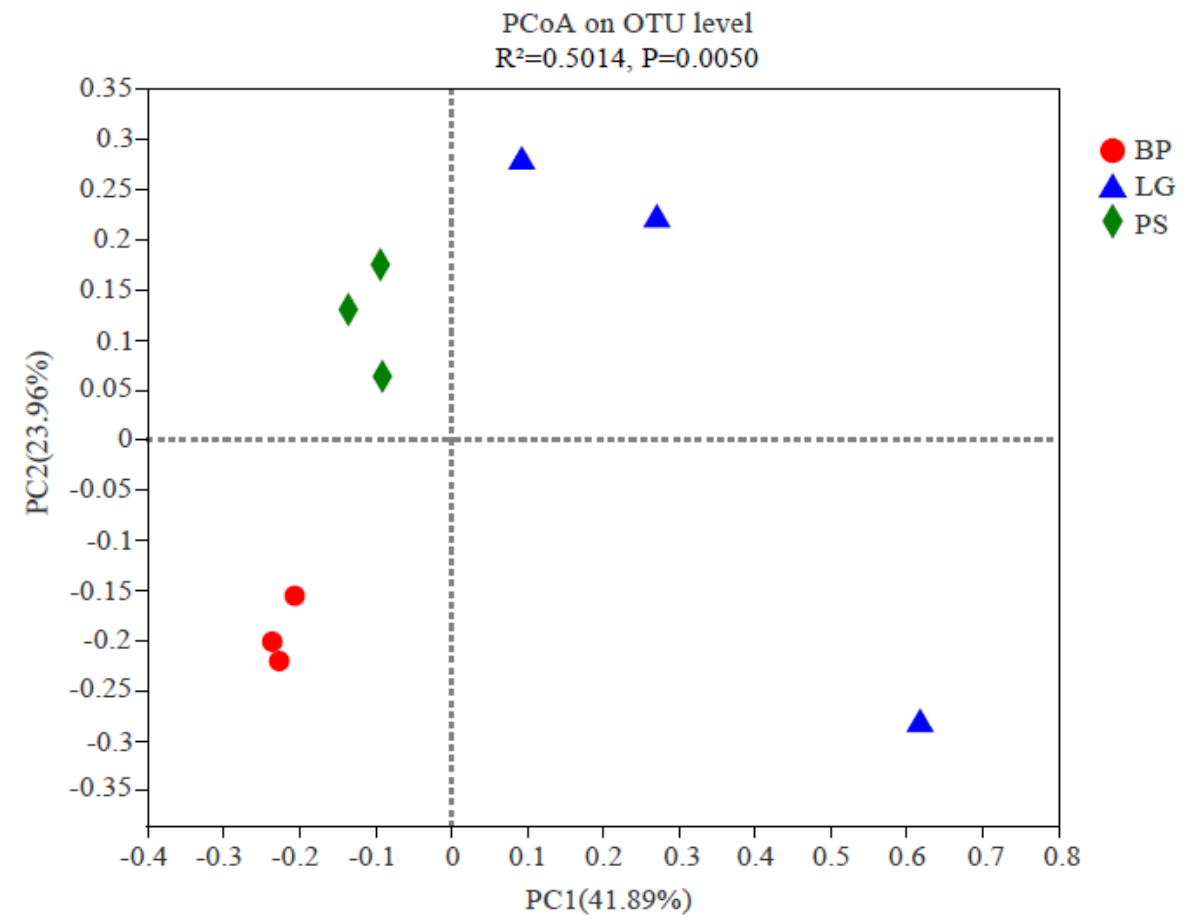

Figure 3. Principal co-ordinates analysis (PCoA) of soil bacterial communities in different forest types

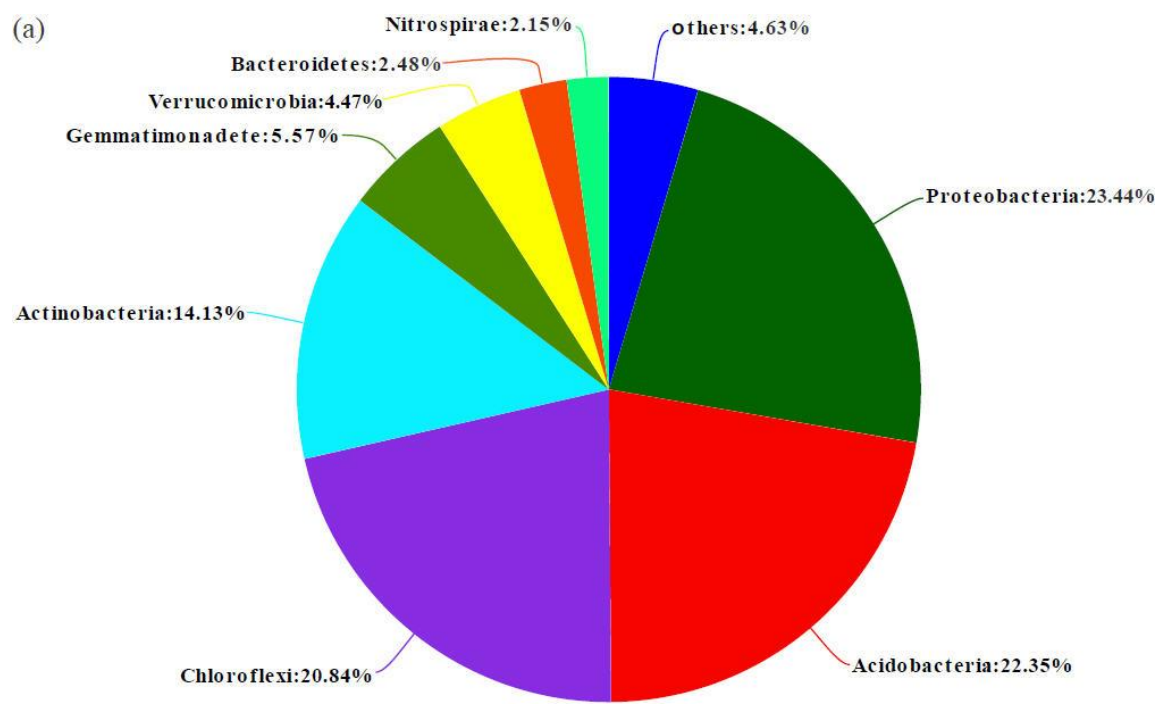



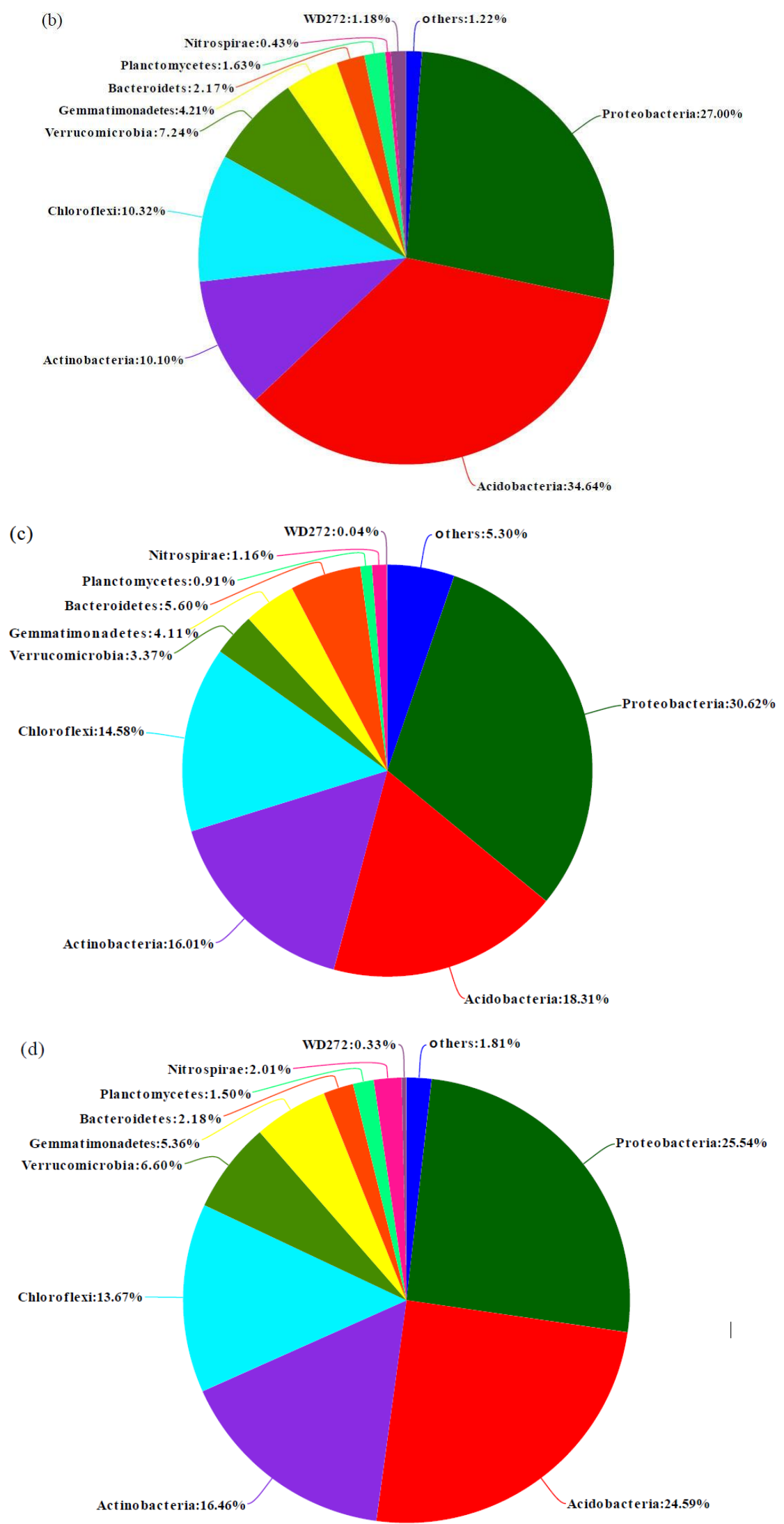

Figure 4. The composition of bacterial community structure at the level of phylum in different forest types. (a) All, (b) Betula platyphylla forest (BP), (c) Larix gmelinii forest (LG), (d) Pinus sylvestris forest $(P S)$ 
The two-sample T-test method was used to analyze the differences on the phylum level. There were two phyla significant differences in the three forests, Acidobacteria $(P<0.01)$ and WD272 $(P<0.01$, Fig. 5a). There were two phyla significant differences between BP and LG, mainly Acidobacteria $(P<0.01)$ and WD272 $(P<0.001$, Fig. 5b). There were four significant differences between BP and PS, mainly Acidobacteria $(P<0.05)$, Gemmatimonadetes $(P<0.05), \quad$ WD272 $(P<0.01), \quad$ Latescibacteria $(P<0.05$, Fig. 5c). There were two significant differences between LG and PS, mainly Acidobacteria $(P<0.05)$ and Firmicutes $(P<0.05$, Fig. $5 d)$.

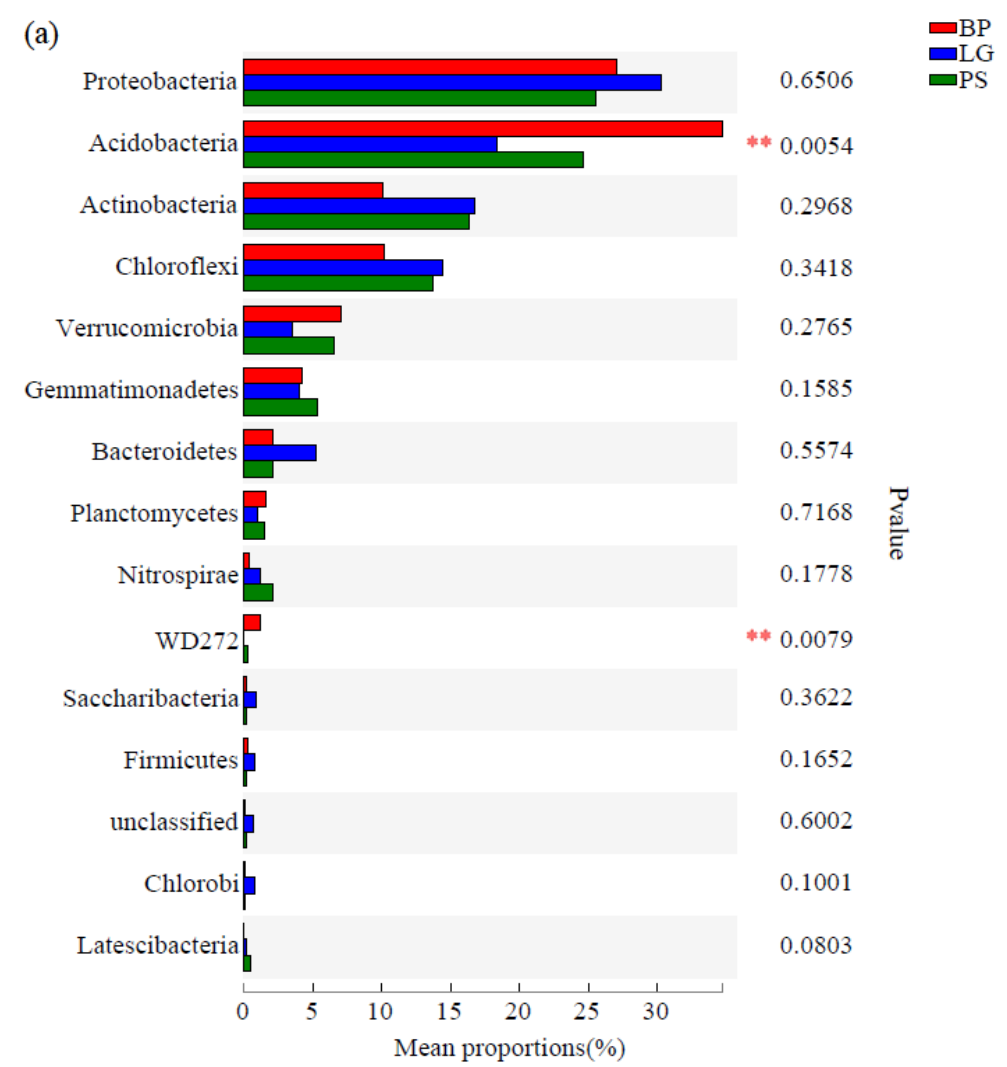

(b)
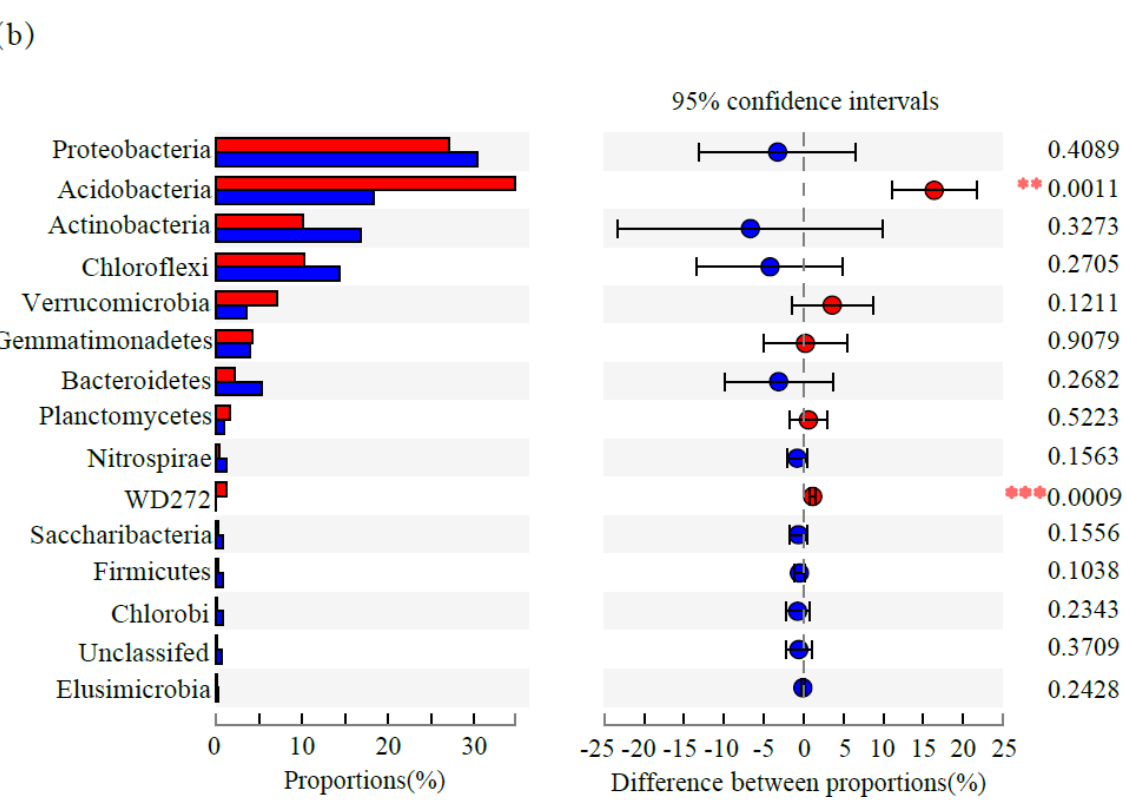
(c)
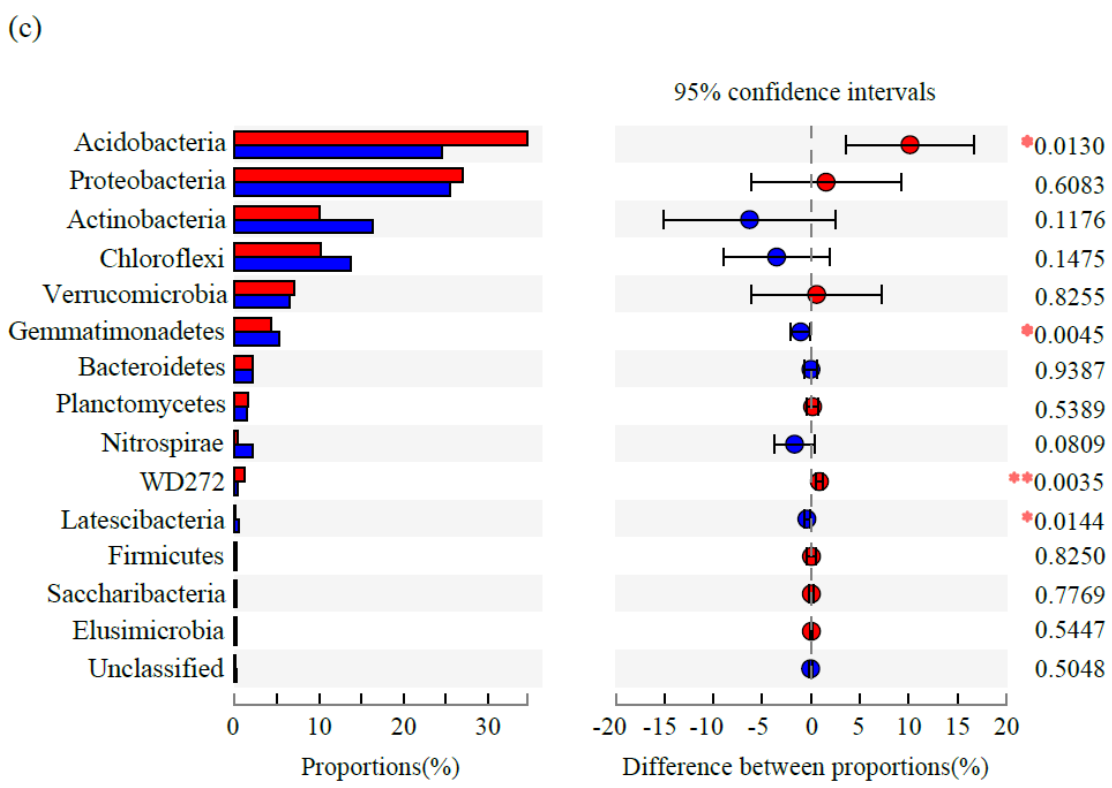

(d)
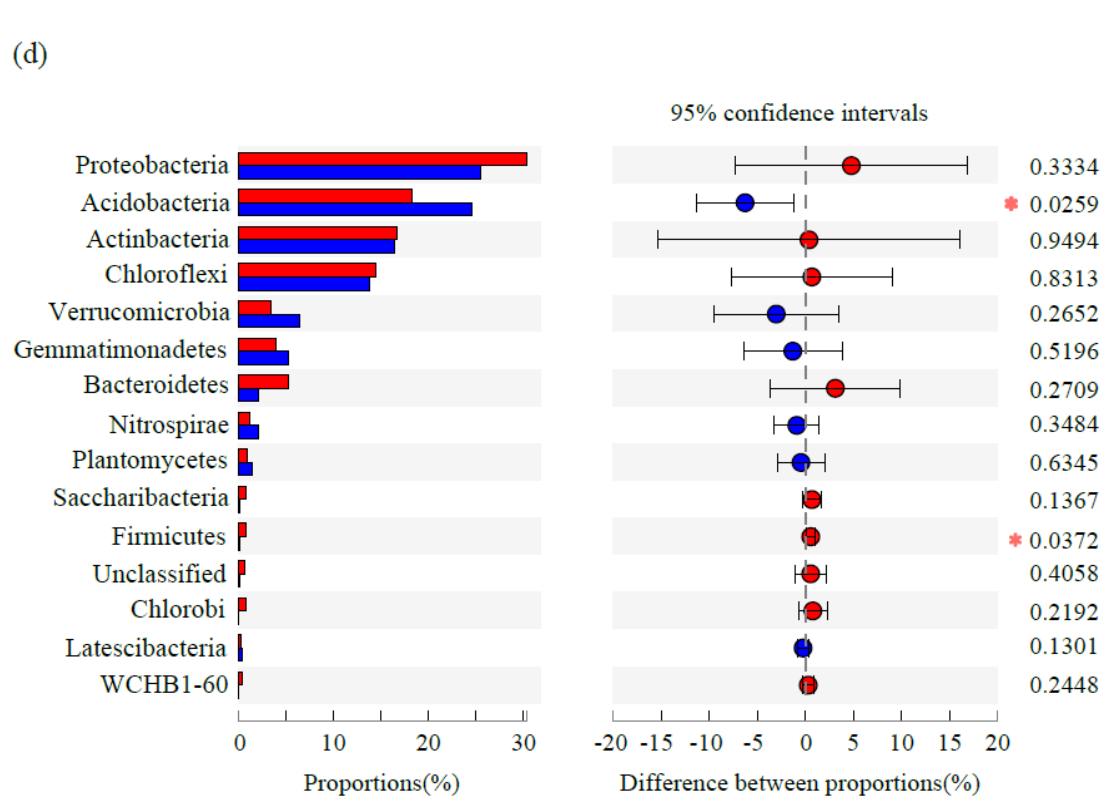

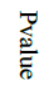

Figure 5. Differences in the abundance of bacterial phylum in different forest types. * $0.01<P \leq 0.05$, ** $0.001<P \leq 0.01$ and $* * * P \leq 0.001$

\section{Redundancy analysis of soil bacterial communities and physicochemical properties of different forest types}

The physicochemical properties of the soil were analyzed redundancy analysis (RDA) with the bacterial community composition at the OTU levels. The analysis results showed in Figure 6. The first-order axis explained $49.31 \%$ and the second-order axis explained $18.48 \%$ of all information. The longer rays of $\mathrm{pH}$ indicate that it had a greater influence on the bacterial community composition, while the shorter rays of TN value indicate that it had less influence on the bacterial community composition. The bacterial community structures of LG were obvious positive affected by $\mathrm{pH}$ and TN, while the bacterial community structures of BP were obvious positive affected by TOC. The bacterial community structures of PS were obvious positive affected by TP. 


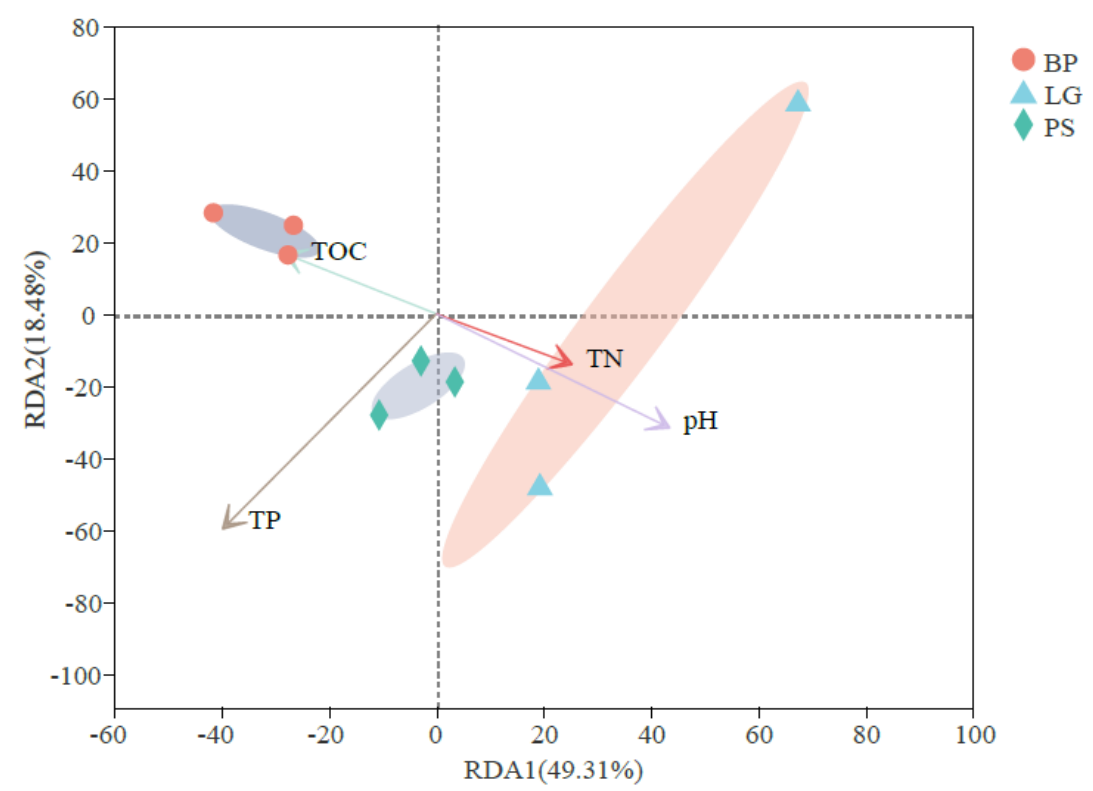

Figure 6. Redundancy analysis (RDA) of soil bacterial community structure and soil physical and chemical properties

\section{Discussion}

\section{Soil physico-chemistry properties of the different forest types}

In this study, we can observe that soil physico-chemistry properties varied significantly among different forest types (Table 2). According to our results, Betula platyphylla forest has reduced the soil total organic carbon and total nitrogen, which was consistent with the study of Yu et al. (2020). This influence may be attributed to long-term forest types change from original Larix gmelinii forest into broadleaf forest succession stage, which led to the soil nutrition lost when the dominant vegetation destroyed. In the cold regions, litter decomposes slowly because of the long winter and low temperature each year, and when the forest vegetation destroys, the soil nutrient, e.g. TOC and TN will lose quickly and cannot recover for a short time (Ramirez et al., 2010). Therefore, in our study, TOC, TN in LG were higher than those in BP. So the forest types would seem to play an important role in regulating soil physico-chemistry properties inside the same cold climate and, in particular, the difference between broadleaf forest and coniferous forest should be noted. Despite the numerous recalcitrant substances were found in the litter from Larix gmelinii forest, such as lignin, resin, tannin, and wax, the dense coniferous litter covering the soil surface impeded air circulation, and reduced the loss of soil nutrients (Thomson et al., 2015). On the contrary, Betula platyphylla forest is often a component of temperate deciduous broadleaf forests; it produces relatively large amount litter, and its nutrient contents in the soil are relatively high (Deng et al., 2019). However, in the cold temperature zone, we found that the litter cannot decompose soon because of the cold temperature and long winter as well as the soil microbial activity. So this is the reason why our result is not consistent with Deng et al. (2019) study. Therefore, in the high latitude permafrost region, the soil nutrition cannot be accumulated soon by litter and once the dominant forest suffered destroyed and led to soil nutrition lost, it would not get recovery by a short time. 


\section{Changes of soil bacterial diversity response to different forest types}

We found that different forest types had distinct soil bacterial abundant diversity (ACE and Chao1) (Table 3). But we do not find obvious different in soil bacterial Shannon and Simpson diversity. There were some studies proved that the crucial role of soil physico-chemistry properties is in altering the soil bacterial diversity during forest succession (Thomson et al., 2015). Soil pH, especially in terms of $\mathrm{C}, \mathrm{N}$, and $\mathrm{P}$ availability, are paramount factors (Tan et al., 2013) and significantly influence bacterial diversity (Zhong et al., 2010). It is reported that bacterial diversity would be decreased when soil $\mathrm{pH}$ was below 6.5 , and soil bacterial diversity would be increased when soil pH close to neutral (Bergkemper et al., 2016). In our study, however, we found that a relatively small $\mathrm{pH}$ range (4.49 to 5.67), making it different to find correlation with bacterial diversity. But previous studies have indicated that bacterial abundant diversity is largely affected by TOC and TN (Siles and Margesin, 2016). Therefore, in our study, TOC and TN concentrations were significantly correlated with bacterial abundant diversity (ACE and Chao1), which was consistent with the observations obtained by Lin et al. (2014).

\section{Changes of soil bacterial composition in different forest types}

Similar to the diversity of bacterial communities, the abundance of the main bacterial phylum is affected by different vegetation types. Different forest types contain different bacterial structures. In this study, Proteobacteria and Acidobacteria were the most abundant phyla in the soil, which was consistent with the research of Sun et al. (2014), which found that the main bacterial types in the forests of Northeast China were Proteobacteria and Acidobacteria. We also found that Acidobacteria, WD272, Gemmatimonadetes, Latescibacteria, Firmicutes varied greatly between different forest types (Fig. 5).

In our study, the relative abundance of Acidobacteria among the three forest types was highest, and in BP was higher than that in LG and PS. Acidobacteria is a dominant phylum in broad leaf forests because it plays a crucial role in litter deposition. In this study, litters in conifer forests are difficult to decompose, but in the broad leaf forests, the litters are easy to decompose. Therefore, this difference of litter composition may be the reason why the abundance of Acidobacteria was higher in BP forests. Similar researches were found by Kopecky et al. (2011). The relative abundance of Actinobacteria in coniferous forests was significantly higher than that in broad-leaved forests may be due to differences in soil organic carbon, total nitrogen, and total phosphorus in different forest types (Table 2). Actinobacteria is usually positive to soil nutrition. We found that the TOC, TN and TP in conifer forest soil were significantly higher than those in broad leaf forest. This may result the abundance of Actinobacteria was higher in coniferous forest types. This has been consistent with study of Guo et al. (2018), which found that with different stages of forest succession, the Actinobacteria abundance and soil organic matter accumulation showed a significantly positive correlation. In addition, Firmicutes were significantly higher in LG than in PS and BP, which also shows that Firmicutes is more adaptable to environments in poorer habitat conditions (Hartmann et al., 2014). The physical-chemical composition of broad-leaved forest and coniferous forest vegetation, the competition among plant species and the change of plant diversity will cause the change of plant litter, organic components and soil bacterial composition. 


\section{Effects of soil environmental factors on different forest types bacterial community}

In terrestrial ecosystems, soil physical-chemical properties are important factors affecting soil microbial communities (Fierer and Jackson, 2006), and are inversely related to the soil bacterial structure composition (Zhou et al., 2017). In our study, we found that there is a clear correlation between bacterial structure composition and $\mathrm{pH}$, TOC, TN and TP, most likely due to the significant difference in soil physical-chemical properties in this study (Fig. 6). The litters of three forest types were different, and the soil physico-chemistry properties were mainly input by litters. Therefore, we can infer that the soil available nutrition of coniferous forest and broad-leaved forest was obviously changed by aboveground litter, and finally affected by soil bacterial diversity. Similar study has proved this phenomenon (Lin et al., 2014).

PCoA results showed that soil bacterial communities of different forest types showed obvious differentiation (Fig. 3), moreover, the bacterial communities of BP and PS were similar and different with those of LG forest, which seemed more various between three replications. Soil bacterial community was controlled by soil physico-chemistrical properties and vegetation. In this study, we selected three forest types, the original Larix gmelinii forest, and the successional forest, including Betula platyphylla forest and Pinus sylvestris forest. The vegetation composition of original Larix gmelinii forest was simplified and the herb was less. However, vegetation compositions of the successional stages were complicated and the herbs also were abundant and similar. Therefore, the bacterial community composition of PS and BP were similar and differed from LG forest. In addition to soil environmental factors, litter decomposition rate, water and heat conditions in active layer, root biomass and exudates may also be important factors driving soil microbial community construction in high latitude cold region forest ecosystem.

\section{Conclusions}

Our results indicate that the soil physical and chemical characteristics and bacterial community composition of different forest types in the Greater Xing'an Mountains were significantly different. Coniferous forests have higher total organic carbon and total nitrogen than broad-leaved forests. In this study, it was found that soil $\mathrm{pH}, \mathrm{TOC}, \mathrm{TN}$ and TP may be the limiting factors of bacterial community structure and composition, and will significantly affect the diversity of bacteria. The results of this study are of great significance for us to understand the impact of forest type changes on soil bacterial community structure. Therefore, to study the coupling relationship between vegetation, microbes and soil environment can provide a deeper understanding for forest ecosystem processes. Further multi-dimensional comprehensive experiments will be carried out in the future to clarify the response mechanism of soil microbial community structure and function to environmental heterogeneity under the background of climate change.

Acknowledgements. This study was supported by the National Natural Science Foundation of China (41501065, 41971151) and supported by the University Nursing Program for Young Scholars with Creative Talents in Heilongjiang Province (UNPYSCT-2017177). 


\section{REFERENCES}

[1] Banerjee, S., Thrall, P. H., Bissett, A., Heijden, M. G. A. V. D., Richardson, A. E. (2018): Linking microbial co-occurrences to soil ecological processes across a woodlandgrassland ecotone. - Ecology and Evolution 8(16): 8217-8230.

[2] Bergkemper, F., Schöler, A., Engel, M., Lang, F., Krüger, J., Schloter, M., Schulz, S. (2016): Phosphorus depletion in forest soils shapes bacterial communities towards phosphorus recycling systems. - Environmental Microbiology 18(6): 1988-2000.

[3] Curlevski, N. J. A., Xu, Z., Anderson, I. C., Cairney, J. W. G. (2010): Soil fungal communities differ in native mixed forest and adjacent Araucaria cunninghamii plantations in subtropical Australia. - Journal of Soils and Sediments 10(7): 1278-1288.

[4] Demeter, I., Makádi, M., Tomócsik, A., Aranyos, T. J., Michéli, E., Posta, K. (2018): Chemical and microbiological properties of Hungarian sandy soils under different management practices. - Applied Ecology and Environmental Research 16(3): 34733488 .

[5] Deng, J., Yin, Y., Luo, J., Zhu, W., Zhou, Y. (2019a): Different revegetation types alter soil physical-chemical characteristics and fungal community in the Baishilazi nature reserve. - PeerJ 6: e6251.

[6] Deng, J., Zhou, Y., Bai, X., Luo, J., Yin, Y., Zhu, W. (2019b): Soil microbial functional diversity responses to different revegetation types in Baishilazi nature reserve. - Polish Journal of Environmental Studies 28(5): 3675-3686.

[7] Dong, L. H., Zhang, L., Li, F. (2019): Evaluation of stand biomass estimation methods for major forest types in the eastern Da Xing'an Mountains, Northeast China. - Forests 10(9): 715.

[8] Fierer, N., Jackson, R. B. (2006): The diversity and biogeography of soil bacterial communities. - Proceedings of the National Academy of Sciences 103(3): 626-631.

[9] Friggens, N. L., Aspray, T. J., Parker, T. C., Subke, J. A., Wookey, P. A. (2019): Spatial patterns in soil organic matter dynamics are shaped by mycorrhizosphere interactions in a treeline forest. - Plant and Soil 447(4): 1-15.

[10] Guo, Y., Chen, X., Wu, Y., Zhang, L., Cheng, J., Wei, G., Lin, Y. (2018): Natural revegetation of a semiarid habitat alters taxonomic and functional diversity of soil microbial communities. - Science of the Total Environment 635: 598-606.

[11] Hartmann, M., Niklaus, P. A., Zimmermann, S., Schmutz, S., Kremer, J., Abarenkov, K., Lüscher, P., Widmer, F., Frey, B. (2014): Resistance and resilience of the forest soil microbiome to logging-associated compaction. - ISME Journal 8(1): 226-244.

[12] Kopecky, J., Kyselkova, M., Omelka, M., Cermak, L., Novotna, J., Grundmann, G. L., Yvan, M. L., Marketa, S. M. (2011): Actinobacterial community dominated by a distinct clade in acidic soil of a waterlogged deciduous forest. - FEMS Microbiology Ecology 78(2): 386-394.

[13] Li, X., Pang, H., Zhao, Y., Sun, M., Zhang, X., Xu, N., He, G., Zhang, H., Sun, G. (2018): Shifts in the bacterial community structure and function along a vegetation gradient in the Great Xing'an Mountains. - Scandinavian Journal of Forest Research 33(2): 103-113.

[14] Lin, Y. T., Hu, H. W., Whitman, W. B., Coleman, D. C., Chiu, C. Y. (2014): Comparison of soil bacterial communities in a natural hardwood forest and coniferous plantations in perhumid subtropical low mountains. - Botanical Studies 55(1): 31-39.

[15] Luo, X., He, H. S., Liang, Y., Fraser, J. S., Li, J. (2018): Mitigating the effects of climate change through harvesting and planting in boreal forests of northeastern China. Sustainability 10(10): 3531 .

[16] Ramirez, K. S., Lauber, C. L., Knight, R., Bradford, M. A., Fierer, N. (2010): Consistent effects of nitrogen fertilization on soil bacterial communities in contrasting systems. Ecology 91(12): 3463-3470. 
[17] Ren, C., Zhang, W., Zhong, Z. K., Han, X., Yang, G., Feng, Y., Ren, G. (2017): Differential responses of soil microbial biomass, diversity, and compositions to altitudinal gradients depend on plant and soil characteristics. - Science of the Total Environment 610-611: 750-758.

[18] Ryan. J., Williams, S. W., Hallgren, G. W. T. W. (2012): Frequency of prescribed burning in an upland oak forest determines soil and litter properties and alters the soil microbial community. - Forest Ecology and Management 265: 241-247.

[19] Siles, J. A., Margesin, R. (2016): Abundance and diversity of bacterial, archaeal, and fungal communities along an altitudinal gradient in alpine forest soils: what are the driving factors. - Microbial Ecology 72(1): 207-220.

[20] Sun, H., Terhonen, E., Koskinen, K., Paulin, L., Kasanen, R., Asiegbu, F. O. (2014): Bacterial diversity and community structure along different peat soils in boreal forest. Applied Soil Ecology 74: 37-45.

[21] Tan, H., Barret, M., Mooij, M. J., Rice, O., Morrissey, J. P., Dobson, A., Griffiths, B., O'Gara, F. (2013): Long-term phosphorus fertilisation increased the diversity of the total bacterial community and the phoD phosphorus mineraliser group in pasture soils. Biology and Fertility of Soils 49(6): 661-672.

[22] Tardy, V., Spor, A., Mathieu, O., Lévèque, J., Terrat, S., Plassart, P., Regnier, T., Bardgett, R. D., Putten, W. H. V. D., Roggero, P. P., Seddaiu, G., Bagella, S., Lemanceau, P., Ranjard, L., Maron, P. A. (2015): Shifts in microbial diversity through land use intensity as drivers of carbon mineralization in soil. - Soil Biology and Biochemistry 90: 204-213.

[23] Thomson, B. C., Tisserant, E., Plassart, P., Uroz, S., Griffiths, R. I., Hannula, S. E., Buée, M., Mougel, C., Ranjard, L., Van, V. J. A., Martin, F., Bailey, M. J., Lemanceau, P. (2015): Soil conditions and land use intensification effects on soil microbial communities across a range of European field sites. - Soil Biology and Biochemistry 88: 403-413.

[24] Tu, L., Peng, Y., Chen, G., Hu, H., Xiao, Y., Hu, T., Liu, L., Tang, Y. (2015): Direct and indirect effects of nitrogen additions on fine root decomposition in a subtropical bamboo forest. - Plant and Soil 389(1-2): 273-288.

[25] Wakelin, S. A., Gerard, E., Van, K. C., Banabas, M., O’Callaghan, M., Nelson, P. N. (2016): Soil physicochemical properties impact more strongly on bacteria and fungi than conversion of grassland to oil palm. - Pedobiologia 59(3): 83-91.

[26] Yu, Y. Y., Li, M. S., Liu, X. L., Yin, W. P., Li, G. F., Mu, L. Q., Cui, X. Y., Cheng, Z. C. (2020): Soil bacterial community composition and diversity of typical permafrost in Greater Khingan Mountains. - Microbiology 47(9): 2759-2770.

[27] Zhong, W., Gu, T., Wang, W., Zhang, B., Lin, X., Huang, Q., Shen, W. (2010): The effects of mineral fertilizer and organic manure on soil microbial community and diversity. - Plant and Soil 326(1): 511-522.

[28] Zhou, X., Guo, Z., Chen, C., Jia, Z. (2017): Soil microbial community structure and diversity are largely influenced by soil $\mathrm{pH}$ and nutrient quality in 78-year-old tree plantations. - Biogeosciences 14(8): 2101-2111. 